\title{
СТОРІНКИ УКРАЇНСЬКОГО МУЗИЧНОГО МИСТЕЦТВА У ПРЕСОДРУКАХ ОТЦЯ МИХАЙЛА ТЕЛЕЖИНСЬКОГО
}

\author{
Молчко У. Б.
}

\section{ВСТУП}

Економічно-політичне та мистецько-освітне життя багатокультурної Галичини в період панування Австро-Угорської імперії, а згодом Польщі проходило складний шлях професійного формування. Зокрема, у галузі музики на перший план виступає «особливий тип «музикантакультурного діяча, аніматора суспільно-духовного життя» ${ }^{1}$, як зазначає Любов Кияновська. Саме до такої категорії митців належить священик, український композитор, культурно-освітній провідник, диригент, видатна суспільно-громадська особа Волині - о. Михайло Тележинський (1886-1939 рр.). Його діяльність припадає на початок $\mathrm{XX}$ ст., який історики слушно називають «волинським ренесансом». Зазначений період мав своїх подвижників. Серед численної плеяди вирізняють найбільш дієвих і талановитих представників, а це: «журналісти П. Певний та І. Підгірський, театральний діяч М. Певний, лікар М. Левицький, Ст. Скрипник - майбутній патріарх Української автокефальної церкви, В. Авраменко - корифей української хореографії, представники духовної традиції, композитори М. Тележинський та А. Річинський. Саме ця група діячів розгорнула вражаючу за обсягом і глибиною практичну діяльність»².

Життєтворчість о. М. Тележинського є багатогранною. Він автор численних композицій. Привертають увагу приблизно 160 опрацювань народних пісень для мішаного хору, а саме: «Зійшов місяць», обробка думи-маршу «На смерть Шевченка» $Є$. Турули, «12 пісень для мішаного хору», «Волинські народні пісні», аранжовані для мішаного хору, куди ввійшло 10 пісень у його записах із Ковельського i Володимир-Волинського повітів, «Співи на Літургії святого Іоана Златоустого», солоспіви (цикл «Айстри» на слова О. Олеся), дитяча

\footnotetext{
${ }^{1}$ Кияновська Л. Галицька музична культура XIX-XX ст. : навчальний посібник. Чернівці : Книги-XXI, 2007. С. 119.

2 Шиманський П. Хорова творчість волинських композиторів першої половини XX ст. : навчальний посібник. Луцьк : Волин. нац. ун-т ім. Лесі Українки, 2010. С. 6.
} 
опера «Дід Мороз»․ Для музики о. М. Тележинського характерні «поетичність, емоційність, глибина» ${ }^{4}$.

Оригінальною сторінкою життєвого шляху волинського митця $є$ його публіцистична діяльність. Пресодруки о. Михайла Тележинського - це неповторне документальне свідчення здобутків українського музичного мистецтва від найдавніших часів і до початку XX ст. Статті, рецензії, дописи, огляди, репортажі, спогади, нариси, що побачили світ на шпальтах періодичних видань «Українська нива», «Українська трибуна», двотижневика «Церква і нарід», дрогобицького журналу «Боян», висвітлювали вартісні культурно-мистецькі та суспільно-громадські події волинського регіону. Газетне друковане слово о. М. Тележинського, яке представляє широку палітру сторінок українського музичного мистецтва, життєтворчості його фундаторів, дописів, що стосуються диригентської тематики, яскравих артефактів концертного життя Волині початку XX ст., малодосліджене і призабуте із плином часу.

Творчий шлях о. М. Тележинського висвітлювали сучасні українські музикознавці П. Шиманський ${ }^{5}$, М. Кучерепа, В. Вісин ${ }^{6}$, також про нього знаходимо інформативні повідомлення в довідковій літературі, упорядниками якої $\epsilon$ А. Муха ${ }^{7}$, П. Медведик ${ }^{8}$. Про творчість митця коротко згадується в багатотомній праці «Історія української музики»" в огляді духовної музики. Публіцистичному доробку присвячені статті П. Шиманського ${ }^{10}$, Л. Філоненка й У. Молчко ${ }^{11}$. Основою джерельної

3 Тележинський Михайло. Муха А. Композитори України та української діаспори : довідник. Київ : Музична Україна, 2004. С. 293-294.

${ }^{4}$ Шиманський П. Музична культура Волині першої половини ХХ ст. Луцьк : Вежа, 2005. С. 144.

5 Шиманський П. Музична культура Волині першої половини ХХ ст. Луцьк : Вежа, 2005. 172 с. ; Шиманський П. Хорова творчість волинських композиторів першої половини XX ст. : навчальний посібник. Луцьк : Волин. нац. ун-т ім. Лесі Українки, 2010. 258 с. ; Шиманський П. Про що розповіли архіви <... . Музика. 1997. № 1. C. $22-23,28$.

${ }_{6}$ Кучерепа М., Вісин В. Волинь 1939-1941pp. Луцьк : Волинська обласна друкарня, 2005. 486 с.

7 Тележинський Михайло. Муха А. Композитори України та української діаспори : довідник. Київ : Музична Україна, 2004. С. 293-294.

8 Тележинський Михайло. Медведик П. Діячі української музичної культури : матеріали до біобібліографічного словника. Записки Наукового товариства імені Шевченка. Львів, 1996. Т. ССХXXII : Праці Музикознавчої комісії. С. 539-540.

${ }^{9}$ Історія української музики : у 6-ти т. Київ : Наукова думка, 1992. Т. 4. С. 109, 649.

10 Шиманський П. Публіцистика М. Тележинського. Проблеми взаємодії мистецтв, педагогіки і практики освіти : збірник наукових праць. Харків, 1999. Вип. 4. С. $162-172$.

11 Філоненко Л., Молчко У. Музикознавчо-публіцистичний нарис Михайла Тележинського «Український композитор Микола Дмитрович Леонтович 
бази цієї праці є раритетні пресодруки о. М. Тележинського, опрацьовані нами у Львівській національній науковій бібліотеці України імені Василя Стефаника.

Метою дослідження $€$ комплексне вивчення журналістського доробку о. М. Тележинського, привернення уваги наукової, мистецькоосвітньої громадськості до публіцистичного надбання композитора, аналіз тематики, жанрового спектра пресодруків, авторського публіцистичного стилю. Відповідно до окресленої мети застосовано методологію дослідження, яка спирається на проблемно-тематичний, системно-аналітичний, компаративний, біографічний, культурноісторичний методи.

Нині пресодруки о. М. Тележинського є раритетними публікаціями, фактично маловідомими сучасникам, але не втратили актуальності в наш час.

\section{1. Тематичні домінанти публіцистичних праць}

\section{о. М. Тележинського з питань історії української музики}

Період другої половини XIX - початку XX ст. у Галичині, Буковині, Волині відзначався значним мистецьким піднесенням, що спонукало суспільно-культурних подвижників українського народу до висвітлення музичних аспектів тогочасного життя в періодичній пресі. Велику роль у цій просвітницькій справі відіграли священики, які, будучи композиторами, диригентами, освітніми діячами, на шпальтах часописів ознайомлювали читачів із здобутками української музики, чим сприяли формуванню національної свідомості. До барвистої когорти духовних провідників-публіцистів - о. Михайла Вербицького, о. Сидора Воробкевича, о. Віктора Матюка, о. Порфирія Бажанського, о. Остапа Нижанківського - належить о. Михайло Тележинський.

(1877-1921)» на сторінках часопису «Українська нива». Минуле $і$ сучасне Волині та Полісся. Володимир-Волинський в історї̈ України і Волині : науковий збірник. Луцьк, 2009. Вип. 32. С. 94-98 ; Філоненко Л., Молчко У. Музикознавчі нариси Михайла Тележинського «Український пісняр Микола Дмитрович Леонтович (1877-1921)» i «Кирило Стеценко (1882-1922)». Музикознавчі студї інституту мистецтв Волинського начіонального університету імені Лесі Українки та Національної музичної академії України імені П.І. Чайковського : збірник наукових праць / упор. О. Коменда. Луцьк : Волин. нац. ун-т. ім. Лесі Українки, 2009. Вип. 4. С. 56-71 ; Філоненко Л., Молчко У. Жанр біографічного нарису в музично-публіцистичній творчості Михайла Тележинського. Музичне життя Волині XIX-XX cm. : колективна монографія / В. Тиможинський та ін. ; заг. ред. П. Шиманського. Луцьк, 2012. С. 51-78 ; Філоненко Л., Молчко У., Шиманський П. Із джерелознавчої спадщини: маловідома стаття Михайла Тележинського «Микола Лисенко». Музична україніка: сучасний вимір : збірник наукових статей. Вип. 7 : Постать Миколи Лисенка в європейському й національному історико-культурному контексті / ред.-упоряд. О. Кушнірук. Київ : ІМФЕ ім. М.Т. Рильського, 2012. С. 336-344. 
У період бездержавності просвітницька роль цього волинського духовного діяча була неоціненною для української спільноти i представлена його чималим журналістським доробком. Провідними тематичними компонентами публікацій митця $\epsilon$ культурнопросвітницькі тексти, у яких розкрився його потенціал популяризатора українського мистецтва. Висвітленням музичних аспектів життя він прагнув привернути увагу тогочасного соціуму до важливих національних артефактів.

Початок журналістської діяльності о. М. Тележинського пов'язаний із виходом у світ газетного матеріалу “Украйнська народна пісня» ${ }^{12}$ на сторінках часопису «Українська нива». П. Шиманський зазначає, що «перша його стаття набула певної символічності, оскільки була присвячена українській народній пісні (100-літньому ювілею 3 дня виходу першої збірки М. Максимовича)» ${ }^{13}$. Звернення до цієї теми характерне для митців другої половини XIX - початку XX ст., оскільки набуло глибокого усвідомлення ними «естетичної цінності і ваги мистецтва, пов'язаного 3 народними джерелами» ${ }^{14}$. Порушенням важливої теми, відзначення опублікування першої збірки українських пісень Михайла Максимовича «Малороссийские песни» (1827р.), журналіст обирає специфічний газетний жанр - звернення. Отець М. Тележинський на сторінках провідного часопису закликає громадськість Волині відзначити цю мистецьку дату концертними імпрезами. У публікації автор прагне якнайглибше донести до читача, свого краянина, важливість фольклорного надбання українського народу. Уже 3 перших рядків відчувається життєрадісно-піднесений тон висловлювання. Отець М. Тележинський наголошує на тому, що наша народна пісня є «глибоко змістовна, високопоетична, «а голосна та правдива, як Господа слово», служить вона (українська пісня У. М.) провідною зіркою в життю нашого народу» ${ }^{15}$. Більшу частину публікації журналіст насичує численним переліком різновидів фольклорних взірців, які творять неоціненну скарбницю нашої мистецької спадщини. Він подає найвідоміші назви пісень побутових, весільних, купальських, обжинкових, веснянок, колискових,

12 Тележинський М. Українська народна пісня. Украӥнська нива. 1927. 28 вересня. Ч. 51 (56). С. 2.

${ }^{13}$ Шиманський П. Музична культура Волині першої половини ХХ ст. Луцьк : Вежа, 2005. С. 23.

14 Загайкевич М. Музикознавство і музична критика. Історія украӥнської музики / АН УРСР. ІМФЕ ім. М.Т. Рильського ; редкол. : М. Гордійчук та ін. Київ : Наукова думка, 1989. Т. 2. С. 438.

15 Телєжинський М. Українська народна пісня. Украӥнська нива. 1927. 28 вересня. Ч. 51 (56). С. 2. 
рекрутських, танцювальних, стрілецьких, зазначає, що це «наша народна музична бібліотека» ${ }^{16}$. Власне тому митець підкреслює важливість проведення згаданих вище концертних урочистостей культурно-освітніми інституціями Волині. За допомогою цитат із віршів Т. Шевченка та висловлювання про народну пісню Леоніда Глібова автор будить літературно-поетичними емоційно-образними засобами читацьку авдиторію до активних дій. Завершує газетний матеріал о. М. Тележинський закликом до самоорганізації у справі поширення фольклорного надбання хоровими колективами Волині, Полісся, Підляшшя, Холмщини, оскільки «не маємо ми спеціяльних музичних шкіл, ні иниих подібних організацій, де б, як у лабораторії, досвідчувалась пісня народня, а звідтам у викристалізованому вигляді передавалась би знову в масу народню» ${ }^{17}$. Цим газетним звернення автор не тільки закликає свідоме громадянство до праці, але й формує їхні світоглядні орієнтири.

Плекаючи національно-освітній рівень української спільноти, журналіст публікує допис "Украӥнські колядки й щеедрівки»" ${ }^{18}$ у двотижневику «Церква і нарід». У доступній формі о. М. Тележинський подає матеріал, у якому представляє неоціненну вартість цього фольклорного пласта, чим впливає на розвиток національного мислення в широких верств української громади. За допомогою літературно-поетичного тону висловлювання автор уже 3 перших рядків наголошує на цінності пісні, у якій зафіксовано "усе минуле життя украӥнського народу від найдавніших часів його існування» ${ }^{19}$. Він порівнює їі з душею, мозком, серцем народу.

Великим надбанням для нашої громадськості є українські колядки i щедрівки, які прийшли до нас крізь тернистий шлях історії «у своїи ангельській чистоті й дівочій красі та свіжссті» ${ }^{20}$. Відзначаючи їхню унікальність, о. М. Тележинський наголошує на суто українському характері. Це проявляється в оригінальних i неповторних пісенноінтонаційних зворотах, бо «украӥнський нарід щзедрою природою обдарований співочим хистом, як мало який інший нарід, не потрібує запозичати у когось чужих $i$ неприродніх духовному його почуванню мелодій» ${ }^{21}$. На популярному рівні автор характеризує формотворчі та

${ }^{16}$ Там само.

17 Там само.

18 Телєжинський М. Українські колядки й щедрівки. Церква $і$ нарiд. 1938. Рік. IV. Ч. 1-2. 1-15 січня. С. 26-29.

19 Телєжинський М. Українські колядки й щедрівки. Церква $і$ нарід. 1938. Рік. IV. Ч. 1-2. 1-15 січня. С. 26.

\footnotetext{
${ }^{20}$ Там само.

21 там само.
} 
ладові особливості українських колядок і щедрівок, вказує на давнє походження, що сягає в поганські часи.

Журналіст звертає увагу читачів на їх численні гармонізації українськими композиторами, а саме Миколою Леонтовичем, Кирилом Стеценком, Олександром Кошицем, Миколою Лисенком, Ярославом Ярославенком та іншими. Він піддає гострій критиці видання колядок із зміненими текстами на сторінках «Богогласника» (1894р., м. Холм). О. М. Тележинський наголошує на етнографічній вартості цього фольклорного пласта, відзначає закордонних учених Яна Коубека, Карела Владіслава Запа, які високо цінували їхню старовинність та неповторність.

У кінці газетного матеріалу о. М. Тележинський висловлює побажання, «щоб наші колядки й щедрівки на віки вічні заховалися в сериі украӥнського народу, передавались з роду в рід через украӥнські иерковно-народні хори й через колядників» ${ }^{22}$, що приведе до сприйняття кожною родиною приналежності до свого національного середовища.

Тему розвитку української музики розкриває об'ємний пресодрук "Церковна музика" 23 , що побачив світ у трьох числах двотижневика «Церква i нарід». За допомогою публіцистичного жанру огляду журналіст висвітлює сторінки становлення українського культового співу. Отець М. Тележинський уже з початкових рядків наголошує на виховному значенні цього мистецтва, яке становить «могутній засіб виховання нашого громадянства, а особливо молоді» ${ }^{24}$. Крізь призму ролі музики в житті стародавньої Греції автор підкреслює іiі роль у формуванні морального характеру людини. Він наводить читачам висловлювання Платона, Аристотеля, розкриває постулати «піфагорійської школи», що торкалися впливу мистецтва звуків. На думку журналіста, як і в інших народів, так і в нас музика завжди служила «иілям релігійного виховання» ${ }^{25}$, тому ми повинні пізнати іiї витоки, щоб створити «нові підвалини до розвитку намої рідної національної церковної музики й співу» ${ }^{26}$.

В огляді о. М. Тележинський застосовує мовленнєві тактики, покликані реалізувати головну мету публікації - виховати і просвітити сучасника. Він ставить запитання до читача про джерела нашого давнього церковного співу і подає грунтовну відповідь, чим насичує

${ }^{22}$ Там само. С. 29.

23 Телєжинський М. Церковна музика. Церква і нарід. 1935. Рік. І. Ч. 14. 1 жовтня. С. 420-422 ; Ч. 15. 15 жовтня. С. 450-454 ; Ч. 17. 15 листопада. С. 526-530.

${ }_{24}$ Телєжинський М. Церковна музика. Церква $i$ нарід. 1935. Рік. І. Ч. 14. 1 жовтня. С. 420.

${ }^{25}$ там само. С. 421.

${ }^{26}$ Там само. 
пресодрук багатим інформативним матеріалом. Автор веде розповідь про витоки церковної музики, аналізує мистецтво XI ст. Спираючись на думки світових учених, зокрема Луї Альбера Бурго-Дюкурде, Юрія Арнольда, Кирила Розумовського, Миколи Кашкіна, Антоніна Преображенського, Степана Смоленського, Дмитра Аллеманова, Івана Левицького, Миколи Грінченка, Юзефа Рейса, журналіст підтримує їхні гіпотези про те, що Русь-Україна мала свій давній церковний спів ще задовго до введення християнства. Ця народна культура дохристиянської доби існує тільки у трансформованих формах у народній творчості. Автор розлого подає інформацію про вплив на церковний спів Київської Русі грецької і болгарської культур, про впровадження восьмигласія Іоанна Дамаскіна. Але це співоче мистецтво, перенесене на Русь, у процесі суспільно-культурного розвою втратило спільність із візантійськими (грецькими) варіантами. Наші хорові «майстри» утворили «свій рідний оригінальний церковний розспів, який $i$ донині має назву знаменного, або крюкового» ${ }^{27}$, як зазначає о. М. Тележинський. Для глибшого осмислення власної історії публіцист наголошує читачеві: «Маючи у себе такий неоцінимо багатий скарб, як нам давній знаменний та київський розспіви та осьмогласіс Івана Дамаскіна; додавши до иього скарбу дорогоиінні мелодї̈ наших релігійних кантів і псалмів <..> - ми повинні дбати про те, щзоб цей наш скарб не покрився порохом забуття в невідомих архівах, а впроваджувався в обіход намого иерковного співу й своєю старовиною завжди нагадував нам про наше славне минуле» ${ }^{28}$.

Виховний дискурс $є$ одним $з$ основних в огляді о. М. Тележинського. Журналіст висвітлює особливості культового національного мистецтва, відзначає велику роль духовного співу в житті нашої церкви, бо «легковажне потрактування иієї справи, особливо в наші часи, сприяє індиферентизмові ци спричинюється до поступового підупадання релігійности» ${ }^{29}$. Митець перелічує декілька причин, які приводять до цього занепаду. Це непрофесійна підготовленість диригентів і дяків, відсутність методичних знань, брак відповідного нотного репертуару, а також видань 3 українським текстом перекладів із Святого Письма та Богослужбових книг. Автор відзначає, що церковні співочі колективи повинні застосовувати у своїй виконавській практиці як український старовинний церковний спів, так $\mathrm{i}$ твори наших композиторів: Д. Бортнянського, М. Березовського, А. Веделя, а також Д. Леонтовича,

27 Телєжинський М. Церковна музика. Церква $і$ нарід. 1935. Рік. І. Ч. 15. 15 жовтня. С. 452.

${ }^{28}$ Там само. С. 454.

29 Телєжинський М. Церковна музика. Церква $і$ нарід. 1935. Рік. І. Ч. 17. 15 листопада. С. 527. 
К. Стеценка, О. Кошиця. Публіцист наголошує, що саме давні культові пісенні наспіви $є$ могутнім джерелом і підставою «для нашого церковного співу, а тим самим $і$ для створення правдивого православно-иерковного національного стилю, відмежсованого від чужсих впливів. Щоб запровадити ці мелодії до хорового церковного співу в намій Церкві, то розуміється, в першу чергу треба дати їм суто церковно правдиву форму сучасної гармонізачії, одночасно заховавши характер тієї епохи, 6 яку вони народилися» ${ }^{30}$.

У газетному матеріалі журналіст завзято обстоював ідею українізації церковної відправи. Він піддав гострій критиці представників московської композиторської школи - О. Гречанінова, М. ІполитоваІванова, О. Кастальського, П. Чеснокова та багатьох інших. «В очах М. Тележинського вони були провідниками «москвофільства» й наділяли церковний спів не притаманним йому світським характером завдяки використанню сучасної гармонічної палітри. Крім того, цих композиторів не могли хвилювати проблеми українізації, що також загострювало ставлення до них» ${ }^{31},-$ зазначає П. Шиманський. Натомість волинський дописувач звертає увагу на твори М. Лисенка, К. Стеценка, О. Кошиця, М. Леонтовича, В. Петрушевського, П. Козицького, для яких «духовна музика $є$ особливою музично-естетичною категорією, інтонаційним вираженням віри, релігійного почуття» ${ }^{32}$.

Завершує публіцистичний матеріал о. М. Тележинський конкретними вказівками щодо поступу у справі розвитку українського церковного співу, які повинні привести до піднесення національної української музичної культури.

\section{2. Мистецька біографістика в газетному доробку о. М. Тележинського}

Волинський журналіст за допомогою комунікативної функції публіцистики здійснює плідну просвітницьку діяльність. У його творчому доробку вирізняються матеріали, присвячені фундаторам української культури: Григорію Сковороді, Миколі Леонтовичу, Кирилу Стеценку, Миколі Лисенку. Ці праці побачили світ на шпальтах таких видань, як: «Українська трибуна», «Українська нива», «Церква i нарід», «Боян». Розкриваючи сторінки життя і творчості корифеїв українського мистецтва, автор застосовує жанр біографічного нарису.

${ }^{30}$ Телєжинський М. Церковна музика. Церква і нарід. 1935. Рік. І. Ч. 17. 15 листопада. С. 529.

${ }^{31}$ Шиманський П. Хорова творчість волинських композиторів першої половини XX ст. : навчальний посібник. Луцьк : Волин. нац. ун-т ім. Лесі Українки, 2010. С. 9.

${ }^{32}$ Там само. С. 10. 
Одним із перших вийшов друком публіцистичний матеріал "Украӥнська пісня. Кирило Григорович Стеценко - украйнський композитор (1882-1922)» ${ }^{33}$, який побачив світ у виданнях «Українська нива», «Боян» ${ }^{34}$. Журналіст обирає жанр нарису, якому властиве ознайомлення читача «з найвизначнішими фактами 3 життя людини, крім того, у тексті може міститись нова, досі невідома інформація про життя героя; <..> зіставлення різних аспектів життя героя, аналіз його поведінки та безпосередньо творчості; <...; в відтворення психологічних мотивів героя, що формують гіпотезу його характеру» ${ }^{35}$. У пресодруці о. М. Тележинський розкриває доленосні події в житті К. Стеценка на тлі біографічних фактів, які представлені у хронологічному порядку. Волинський журналіст був особисто знайомий із композитором, тому вважав за потрібне зафіксувати свої спогади про митця на сторінках періодичної преси.

Варто зазначити, що біографію К. Стеценка впродовж багатьох років «було стерилізовано, вкладено у «прокрустове ложе» тих ідеологічних схем, які виробила компартійна система, припасовуючи життєписи славних діячів віддаленого й близького минулого до своїх потреб і завдань» ${ }^{36}$. На початку $90-\mathrm{x}$ p. XX ст. Григорій Зленко віднайшов і опублікував у статті «Забута біографія» нарис брата митця Петра Стеценка «Протоієрей Кирило Григорович Стеценко» ${ }^{37}$, який проливає світло на життєпис фундатора української музики. Пресовий документ о. М. Тележинського $\epsilon$ ще одним стеценкознавчим документальним джерелом, у якому описано маловідомі факти із життя композитора.

Журналіст подає матеріал у вигляді вільної розповіді. Допис розпочинається вступом, де публіцист у піднесеному тоні пише про концертну мандрівку Європою Української республіканської капели під керівництвом диригента О. Кошиця, під час якої «славні імена наших твориів украӥнської пісні й музики стали відомі широкому

33 Телєжинський М. Українська пісня. Кирило Григорович Стеценко український композитор (1882-1922). Украӥнська нива. 1927. Ч. 57 (62). 24 жовтня. С. $3-4$; Ч. 58 (63). 28 жовтня. С. 4 ; Ч. 59 (64). 1 листопада. С. 4.

34 Тележинський М. Кирило Стеценко. Боян. 1930. № № 6-7. Червень. С. 69-72.

35 Нечипорук А. Жанрова інтерпретація літературного портрета в межах сучасних масових комунікацій (на прикладі газети «Столичні новини»). Слова у кантэксие часу : матэрыялы IV Міжнародної навуково-практичної канеренції., прысвеченої 90-годдзю 3 дня нараджэння доктора філал. навук, праф. А.І. Наркевіча, Мінск, 14-15 сак. 2019 г. / Беларус. дзярж. ун-т ; рэдкал. : В. Самусевіч (адк. рэд.) і інш.. Мінск : БДУ, 2019. С. 277.

36 Зленко Г. Забута біографія. Музика. 1994. № 3. С. 25.

37 Зленко Г. Забута біографія. Музика. 1994. № 3. С. 25-27. 
світові» ${ }^{38}$. Прагнучи зацікавити читача, він ставить запитання: «А чи ж ми, украӥнці, сьогодні можемо похвалитися своїм знанням про життя $i$ музичну творчість наших видатних композиторів?» ${ }^{39}$ Власне тому митець представляє духовно-життєвий портрет К. Стеценка на тлі його біографічних фактів та творчості. У нарисі автор стисло подає шлях професійного становлення молодого музиканта. Крізь призму особистих спогадів о. М. Тележинський розкриває композиторські напрацювання у створенні низки церковних творів, які вирізнялися українськістю. «Сам я (о. М. Тележинський - У. М.), будучи диригентом семинарського хору, на протязі трьох літ (4, 5, 6 кляси) 3 приємністю співав молоді свіжі твори Стеценка, хоч частенько й діставав зауваження від ректора арх. Амвросія: «што ви пойотє еті малоросійскіє марші Стеценковскіє? <...> Лучше не пойте їх» ${ }^{40},-$ пише журналіст. Ці переслідування супроводжували митця все життя. Доля закидувала його все далі від Києва - центра культурно-освітнього і музичного життя. Автор вияскравлює особливі факти його біографії на тлі українських суспільно-політичних настроїв XX ст., а саме за часів проводу Симона Петлюри.

Пресодрук о. М. Тележинського пронизаний цікавими біографічними фактами, які вияскравлюють непрості відносини 3 О. Кошицем на тлі організації та підготовки Української республіканської капели до європейського турне. Автор змальовує композитора як амбіційну постать. Згадуючи події зі свого життя, він пише: «Так звана «отаманія» у всіх галузях державного життя шаленим темпом гналася навипередки $i$, як заразлива хороба, причіплювалася до багатьох, щңо були в рядах У. Н. Р. Хорував на «отаманію» де-хто $і$ в державній Капелі, захорував на неї Стеценко. Отож, коли Капела була в Стрию, зустрічаю якось на ст. Броди К. Стеценка та й питаю його: «Куди ие ти голубе, мандруєш?» А він каже: «Іду до Стрия розносити Капелу Кошиия <...> Там щяось страшне в ній діється. Мабуть прийдеться ї̈ перечистити, взяти до своїх рук. Тай виїхати з нею за кордон $<\ldots>»{ }^{41}$

Щоб передати більш цілісно образ митця, публіцист аналізує місце його творчості у скарбниці української музики. Цінними $\epsilon$ висловлювання о. М. Тележинського щодо цього: «У всіх музичних творах Стеценка чи то світських, чи церковних переважає

38 Телєжинський М. Українська пісня. Кирило Григорович Стеценко - український композитор (1882-1922). Украӥнська нива. 1927. Ч. 57 (62). 24 жовтня. С. 3.

${ }^{39}$ Там само. С. 4.

40 Там само.

41 Телєжинський М. Українська пісня. Кирило Григорович Стеценко - український композитор (1882-1922). Украӥнська нива. 1927. Ч. 58 (63). 28 жовтня. С. 4. 
характерний колорит начіональної украӥнської музики, народньої пісні. Твори його то тяжко сумні, журливі, навіть глибоко драматичні (y «Гайдамаках»), то ніжно ліричні, сентиментально-жартівливі $i$ гучно веселі. Найбільшу увагу звертають на себе його хоральні співи (мужеські, жіночі ц мішані) своєю гармонійною простотою і зрозумілістю, прибрані в строго систематизовану музичну форму. Мелодію в його творах широко розвинено, рясно уквітчано барвистими акордами, переплетено модуляційними секвенціями; струнка вона та гнучка, мила та прекрасна, як молода на весіллі» ${ }^{42}$. Вартісною є оцінка журналістом значення його релігійних творів, у яких «панує виключно національний украӥнський церковний характер» ${ }^{43}$. У нарисі автор подає назви композицій К. Стеценка, звертає таким чином увагу сучасників на багате жанрове розмаїття музики митця.

Газетний матеріал «Українська пісня. Кирило Григорович Стеценко - український композитор (1882-1922)» пронизаний роздумами публіциста про значення української музики, іiї визначного фундатора, які сприяли формуванню націоцентричного культурноінформаційного простору, отже, громадянського суспільства.

Складний життєвий шлях Миколи Леонтовича о. М. Тележинський подає сучаснику висвітленням доленосних сторінок його біографії в публікації «Украйнська народна пісня. Микола Дмитрович Леонтович украйнський композитор (1877-1921)»"4. У публіцистичному матеріалі простежується тема переслідування тогочасною більшовицькою владою українських митців. Автор акцентує увагу пересічних громадян на маловідомих фактах смерті композитора. Власне біографічний дискурс журналіст розпочинає 3 детального опису трагічного вбивства М. Леонтовича, яким показує підступність та жорстокість суспільнополітичної державної машини, а також змушує сучасників осмислити ці тяжкі часи. Роздумуючи над драматизмом обірваного життя, публіцист зазначає, що його смерть - «невимовна тяжка втрата для украӥнського мистеитва і всього украйнського громадянства» ${ }^{45}$.

Щоб зрозуміти значення композиторського доробку М. Леонтовича для нашої культури, о. М. Тележинський грунтовно характеризує його музичне надбання, у якому вражає «своєрідна, ні від кого не запозичена, контрапунктиція, надзвичайно иіккава гармонічна основа, гра звуковими контрастами, точна, правдива, характерна, мальовнича передача всіх

42 Телєжинський М. Українська пісня. Кирило Григорович Стеценко - український композитор (1882-1922). Українська нива. 1927. Ч. 58 (63). 28 жовтня. С. 4.

43 Там само.

44 Телєжинський М. Українська народна пісня. Микола Дмитрович Леонтович український композитор (1877-1921). Украӥнська нива. 1928. Ч. 8 (89). С. 3-4.

${ }^{45}$ Там само. C. 3. 
моментів з життя природи, - $і$ все ие на фоні оригінальної украӥнської мелодії» ${ }^{46}$. Для художнього відображення творчої лабораторії композитора журналіст застосовує чимало прикметників, чим піднімає в нарисі емотивне сприйняття матеріалу. Він пише: «Звичайна, проста мелодія украӥнської народньої пісні, що прибрана композитором М. Леонтовичем в дорогоиінну музично-художню тогу, уквітчана блискучими музичними діамантами і мрійливо-журливими перлинами, виглядає, як пишна та славна украӥнська царівна, перед якою побожно схиляють свої голови найвельможніші і найзнатніші музичні мудреці світової слави» ${ }^{47}$. Автор детально перелічує назви творів митця, дає аналіз його окремих композицій. Журналіст обрамлює нарис поверненням до біографічних віх композитора, чим «цементує» публіцистичний матеріал. Завершує газетний матеріал о. М. Тележинський думкою про те, що «пам'ять $і$ слава про нього, будуть вічно жити в сериях українських, доки сонце на небі світитиме, доки житимуть люде» ${ }^{48}$. Усвідомлюючи цінність описаних фактів із життя композитора М. Леонтовича, автор друкує цей нарис у галицькому журналі «Боян» 49 .

Газетний матеріал $є$ вартісним джерелознавчим документом, де підтверджується трагічна смерть М. Леонтовича від рук більшовицького агента. Цей факт замовчувався в біографії композитора в радянські часи. Нарис засвідчує, що о. М. Тележинський був сміливим журналістом-борцем, який не боявся на початку XX ст. висвітлювати правдиву дійсність радянської України. Акцентування в газетному матеріалі на українській сутності в розвитку музичного мистецтва, творчих досягнень визначних іiі фундаторів вказує на україноцентричну громадянську позицію о. М. Тележинського і є стрижневою парадигмою його публіцистики.

Потреба донести до тогочасного громадянства розуміння ваги української культури спонукала журналіста до постійного висвітлювання життєтворчостей ії фундаторів через публіцистичні ресурси, зокрема двотижневик «Церква i нарід». Культурно-просвітницька тематика пресодруків о. М. Тележинського знайшла продовження в нарисі «Микола Лисенко (в 25 роковини смерти)»" ${ }^{50}$. У ньому він упроваджує

46 Там само.

47 Там само.

48 Телєжинський М. Українська народна пісня. Микола Дмитрович Леонтович український композитор (1877-1921). Украӥнська нива. 1928. Ч. 8 (89). С. 4.

${ }_{49}$ Телєжинський М. Український пісняр Микола Дмитрович Леонтович. Боян. 1930. Січень. № 1. С. 2-3.

50 Телєжинський М. Микола Лисенко (в 25 роковини смерти). Церква $і$ нарід. 1937. Рік III. Ч. 20. 15 жовтня. С. 687-691. 
ідею формування світогляду молодого покоління через знання творців національного мистецтва. Свій публіцистичний матеріал автор розпочинає вступом, у якому пише: «Кожний культурний народ $\epsilon$ щасливий $і$ гордий, коли він має свойх велетнів духа, щчо народилися з ласки Божої, зросли й принесли шляхетні овочі своєю творчою пращею на ниві народній» ${ }^{51}$. Журналіст наголошує, що М. Лисенко «периий 3 украӥнських композиторів створив національну художню музику свого народу, високо підніс ї̈ до рівня всесвітньої музики і вивів у широкий світ поміж європейських народів» ${ }^{52}$.

Невід'ємним аспектом публіцистичних нарисів є виклад життєпису митців. Подаючи біографію композитора, о. М. Тележинський підкреслює великий вплив української народної пісні на творчість Миколи Лисенка. Значну увагу автор приділив характеристиці його музичної спадщини, крізь призму якої окреслено творчі орієнтири. Серед об'ємного надбання визначне місце посідає «Музика до Кобзаря», про яку журналіст пише, що вона правдива «як Господа Слово» ${ }^{53}$. Біографічний нарис супроводжується переліком композицій М. Лисенка.

Змальовуючи портрет корифея української музики, о. М. Тележинський відзначає його неоціненну роль для громадянського суспільства, оскільки він був «не тільки великим художником-композитором, але $\check{u}$ великим громадянином-

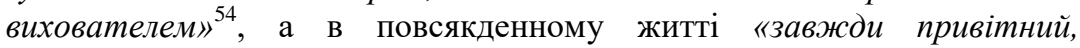
дотепний, повний украйнського гумору, статечний аристократ і разом такий простий і доступний у товариському обходженні» 55 .

Пресодрук о. М. Тележинського містить цікавий спогадовий матеріал щодо участі М. Лисенка в концертній програмі святкової академії на честь Тараса Шевченка в 1908 р. Диригуючи власним твором «Жалібний марш» («Вмер батько наш!») на слова Лесі Українки для мішаного хору в супроводі оркестру, композитор втратив контакт із музикантами. Це привело композитора до сильного емоційного переживання, тому твір виконувався із другої спроби. Автор настільки детально описує цей життєвий факт, а також спілкування М. Лисенка 3 артистами, що перед нами постає митець, опанований почуттям великої професійної відповідальності. Для завершення нарису о. М. Тележинський послуговується цитуванням поезії Лесі Українки:

${ }^{51}$ Там само. С. 687.

52 Телєжинський М. Микола Лисенко (в 25 роковини смерти). Церква $і$ нарід. 1937. Рік III. Ч. 20. 15 жовтня. С. 687.

${ }^{53}$ Там само. С. 688.

${ }^{54}$ Там само.

55 Там само. 
«Вирядили ми свого батенька в далеку дорогу, А за його Украӥна-ненька помолиться Богу $<\ldots>{ }^{56}$.

Крізь біографічні події, характеристику творчості, об'ємний спогадовий матеріал публіцист представляє М. Лисенка як особистість, що $є$ керманичем нашого суспільного життя, але водночас залишається людиною. Це дає нам підстави стверджувати про переважання людиноцентричного світорозуміння у пресодруках о. М. Тележинського.

У 1930 р. на шпальтах «Української ниви» виходить друком допис "Григорій Сковорода (учений філософ-проповіднк)" ${ }^{57}$ за підписом М. Т-ський. За логічністю викладу матеріалу, переконливістю тверджень щодо важливості служіння українському народу, підкреслення ролі музики в житті філософа, схожість ініціалів спонукає нас до думки, що цей біографічний нарис належить авторству о. М. Тележинського.

Публіцист зображає Г. Сковороду як особу 3 багатогранними талантами. Навчаючись в Київській академії, він опанував декілька мов, вивчав філософію, богословські науки, математику, природознавство. Журналіст відзначає, що юнак мав гарний голос i співав в академічному хорі. Його одного 3 перших було відібрано до придворної капели. Після відрахування з навчання молодий філософ мандрував Італією, Польщею, Німеччиною. Автор нарису акцентує, що «особливо любив Сковорода музику. Він компонував духовні концерти, деякі псальми (по зразку псальм св. Дмитрія митрополита Ростовського) різні стихири, а також де-що з літургії. Усі його твори гармонійні, прості й милі для душі. Опріч того він добре грав на скрипиі, сопілці, бандурі ц̌ гуслях» ${ }^{58}$. Газетний матеріал понизаний різноманітними фактами із життя філософа, де він показаний як вільний, незалежний митець. У віці 53-х років Г. Сковорода обирає мандрівний спосіб життя. Імператриця Катерина II, дізнавшись про це, через Григорія Потьомкіна запропонувала філософу переселитися з України до Петербурга. Але вона отримала відповідь, гідну українця: «Моя сопілка і вівия мені дорожчі від иарського віния!»». Український учений-проповідник навчав простих людей, за що отримав звання народного вчителя. «Його музичні твори (канти ц̆ псальми)

56 Тележинський М. Микола Лисенко (в 25 роковини смерти). Церква $i$ нарід. 1937. Рік ІІІ. Ч. 20. 15 жовтня. С. 691.

${ }^{57}$ Т-[елєжин]ський М. Григорій Сковорода (Український філософ-проповідник). Українська нива. 1930. Ч. 49 (271). С. 2.

58 Там само.

59 Т-[елєжин]ський М. Григорій Сковорода (Український філософ-проповідник). Українська нива. 1930. Ч. 49 (271). С. 2. 
з замилуванням слухали не вельможні пани, а простий нарід: селяни, козаки, чумаки, бурлаки та міщане. Але сильніш за всі свої твори впливав він на народні маси сам своєю власною особою, своїм поступуванням і прикладом. <..> Слава про нього живе між нами ще й досі і житиме по вік віку» ${ }^{60}$, - відзначає о. М. Тележинський.

Біографічний нарис «Григорій Сковорода (Український філософпроповідник)» утверджує велич постаті народного пророка, що стала міцним фундаментом для національного самоусвідомлення українців.

\section{ВИСНОВКИ}

Публіцист о. М. Тележинський - один із найавторитетніших суспільно-релігійних, культурно-освітніх керманичів Волині кінця XIX - початку XX ст. Співпрацюючи 3 українськими часописами, музичний діяч творив національний мистецький медіапростір.

Встановлено, що тематичними домінантами журналістського доробку є сторінки історії українського мистецтва, зокрема фольклору, церковно-музичної естетики під час богослужінь, життєписи фундаторів національної культури, а також тогочасне концертне життя краю, дописи про диригентську майстерність. Публіцистична діяльність на сторінках часописів «Українська трибуна», «Українська нива», «Церква i нарід», «Боян» стала підмурівком для розвитку музичної критики на волинській землі в умовах бездержав'я. Проаналізована частина пресодруків о. М. Тележинського, що торкаються важливих культурно-мистецьких аспектів нашої культури, засвідчує значний внесок митця в українську музичну історіографію. Його публіцистична спадщина заслуговує на вдумливе вивчення.

Культурно-просвітницькі дописи о. М. Тележинського популяризують серед широкого загалу громадян фольклорну спадщину, напрацювання в царині релігійної музики, творчі здобутки корифеїв нашої культури. Серед публіцистичного доробку - життєписи М. Лисенка, М. Леонтовича, К. Стеценка та вперше введений у науковий обіг біографічний нарис про Г. Сковороду, якими автор у толерантній формі доносив значущість фундаторів української музики. Обстоюючи сутність національного мистецтва, журналіст гостро викриває вплив москвофільства, чим обстоює національні інтереси українства. Його пресодрукам властиві надмірна емоційність, гострота вислову, полемічність. Газетні дописи прості у викладі матеріалу, що створює можливість легкого сприйняття пересічними читачами. Арсенал

${ }^{60}$ Т-[елєжин]ський М. Григорій Сковорода (Український філософ-проповідник). Українська нива. 1930. Ч. 49 (271). С. 2. 
публіцистичних жанрів о. М. Тележинського становлять інформаційні, аналітичні, художньо-публіцистичні дописи.

Публіцистика о. М. Тележинського є гуманістичною, оскільки висвітлює важливі світоглядні засади, а саме людиноцентричності, націоцентричності й україноцентричності, які $є$ вкрай актуальними для сьогочасного суспільно-культурного розвитку України.

\section{АНОТАЦІЯ}

Дослідження висвітлює публіцистичну спадщину волинського суспільно-культурного діяча початку XX століття о. Михайла Тележинського. Проаналізовано музично-критичні статті, що побачили світ на сторінках часописів «Українська нива», «Українська трибуна», «Церква i нарід», «Боян». Наведено огляд газетного доробку о. М. Тележинського. Досліджено тематику публікацій, жанровий спектр, професійну аргументованість та літературну майстерність. Розглянуто фактологічну насиченість пресодруків о. М. Тележинського. Здійснено систематизацію інформаційного газетного матеріалу за музикознавчою значущістю. Виявлено особливості публіцистичного стилю митця, який своєю творчістю впливав на формування національної свідомості українців.

\section{SUMMARY}

The research highlights the journalistic heritage of the Volyn socio-cultural figure of the early twentieth century, Fr. Mykhailo Telezhynskyi. During this period, the economic, political, artistic and educational life of multicultural Galicia during the rule of the Austro-Hungarian Empire, and later Poland was on a difficult path of professional formation, where a special type of musiciancultural figure, animator of social and spiritual life came to fore. This category of artists includes a priest, ukrainian composer, cultural, and educational leader, conductor, a prominent public figure of Volyn - Fr. Mykhailo Telezhynskyi (1886-1939). His journalistic activity is the original page of the volyn artist's lifeway. Press releases of Fr. Mykhailo Telezhynskyi is unique documentary evidence of the ukrainian musical art achievements from ancient times to the beginning of the twentieth century. Articles, notices, posts, reviews, reports, memoirs, essays published in the columns of periodicals "Ukrainska Nyva", "Ukrainska Trybuna", biweekly "Tserkva I Narid", drohobych magazine "Boyan" covered valuable cultural, artistic, and social public events of the volyn region. Newspaper printed word of Fr. M. Telezhynskyi, which represents a wide range of the Ukrainian musical art pages, the life creations of its founders, the author's performing and conducting reflections, vivid artifacts of concert life in Volyn in the early twentieth century is little researched and forgotten over time. 
The creative path of Fr. M. Telezhynskyi was covered by modern ukrainian musicologists P. Shymanskyi, M. Kucherepa, and V. Visyn, as well as by informative reports in the reference literature, compiled by A. Mukha, P. Medvedyk. The artist's compositions are briefly mentioned in the multi-volume work "History of Ukrainian Music" in the review of sacred music. Articles by P. Shymanskyi, L. Filonenko, and U. Molchko are devoted to the journalistic work. The basis of the source base of this study are rare press releases of the artist, worked up by the author in the Lviv National Scientific Library of Ukraine named after Vasyl Stefanyk.

The purpose of the research is a comprehensive study of the journalistic achievements of Fr. M. Telezhynskyi, drawing the attention of the scientific, artistic, and educational community to the journalistic heritage of the composer, analysis of topics, genre range of press releases, author's journalistic style.

Today the press releases of Fr. M. Telezhynskyi are rare and, in fact, little known to contemporaries. They have not lost their relevance in our time.

The research methodology is based on system-analytical and comparative, biographical, cultural, and historical methods.

The scientific novelty lies in the introduction into scientific circulation of the press release of Fr. M. Telezhynskyi "Hryhoriy Skovoroda (Ukrainian philosopher-preacher)".

The study analyzes the musical critical articles published in the periodicals "Ukrainska Nyva", "Ukrainska Trybuna", "Tserkva I Narid", "Boyan". There is cited an overview of the newspaper work of Fr. M. Telezhynskyi. The topics of publications, genre spectrum, professional argumentation, and literary skills are studied. The factual saturation of press releases of Fr. M. Telezhynskyi is observed. The systematization of informational newspaper material by musicological significance has been carried out. The peculiarities of the artist's journalistic style, which influenced the formation of the national consciousness of ukrainians, are revealed.

Publicist Fr. M. Telezhynskyi was one of the most authoritative social, religious, cultural, and educational leaders of Volyn in the late nineteenth early twentieth centuries. Collaborating with ukrainian magazines, the musician worked on the creation of a national art media space.

It is determined that the thematic dominants of the journalistic work are the pages of the ukrainian art history, in particular folklore, church and musical aesthetics during services, biographies of the founders of national culture, as well as the concert life of the region, articles on conducting skills. Journalistic activity on the pages of "Ukrainska Trybuna", "Ukrainska Nyva", "Tserkva I Narid", "Boyan" became the foundation of the music criticism development in the volyn land in the conditions of statelessness. The analyzed part of the press releases of Fr. M. Telezhynskyi, concerning 
important cultural and artistic aspects of our culture testify that he made a significant contribution to the ukrainian musical historiography, which deserves to be studied.

Cultural and educational press releases of Fr. M. Telezhynskyi popularize, among the general public, folklore heritage, work in the field of religious music, creative achievements of the luminaries of our culture. Among the journalistic works are the biographies of M. Lysenko, M. Leontovych, $\mathrm{K}$. Stetsenko and for the first time introduced into scientific circulation biographical essay about H. Skovoroda, with which the author in a tolerant form conveyed the importance of the ukrainian music founders. Defending the importance of national art, the journalist sharply exposes the influence of galician russophilia, and by this he defends the national interests of ukrainians, so such press releases are characterized by excessive emotionality, the sharpness of expression, polemics. His newspaper articles are characterized by the simplicity of the material presented, which makes them easy to perceive by ordinary readers. The variety of newspaper genres of Fr. M. Telezhynskyi includes informational, analytical, artistic, and journalistic posts.

Journalism of Fr. M. Telezhynskyi is humanistic, as it highlights important worldviews, namely human-centeredness, nation-centeredness and ukrainocentricity, which are relevant in the current social-cultural development of Ukraine.

\section{ЛІТЕРАТУРА}

1. Історія української музики : у 6-ти т. Київ : Наукова думка, 1992. T. 4. $649 \mathrm{c}$.

2. Загайкевич М. Музикознавство і музична критика. Iсторія украӥнської музики / АН УРСР. Ін-т мист-ва, фолькл. та етногр. ім. М.Т. Рильського; редкол. : М. Гордійчук та ін. Київ : Наукова думка, 1989. T. 2. С. $424-445$.

3. Зленко Г. Забута біографія. Музика. 1994. № 3. С. 25-27.

4. Кияновська Л. Галицька музична культура XIX-XX ст. : навчальний посібник. Чернівці : Книги- XXI, 2007. 424 с.

5. Кучерепа М., Вісин В. Волинь 1939-1941 рр. Луцьк : Волинська обласна друкарня, 2005. 486 с.

6. Нечипорук А. Жанрова інтерпретація літературного портрета в межах сучасних масових комунікацій (на прикладі газети «Столичні новини»). Слова у кантэксие часу : матэрыяльы IV Міжнар. навуковопрактичної канференції, прысвеченої 90-годдзю з дня нараджэння докт. філал. навук, праф. А.І. Наркевіча, Мінск, 14-15 сак. 2019 г. I Беларус. дзярж. ун-т ; рэдкал.: В. М. Самусевіч (адк. рэд.) [і інш.]. Мінск : БДУ, 2019. С. 276-281. 
7. Т-[елєжин]ський М. Григорій Сковорода (Український філософпроповідник). Украӥнська нива. 1930. Ч. 49 (271). С. 2.

8. Телєжинський М. Кирило Стеценко. Боян. 1930. Червень. № № 6-7. С. 69-72.

9. Телєжинський М. Микола Лисенко. Церква і нарід. 1937. Рік III. Ч. 20. 15 жовтня. С. 687-691.

10. Тележинський Михайло. Медведик П. Діячі української музичної культури : матеріали до бібліографічного словника. Записки Наукового товариства імені Шевченка. Львів, 1996. Т. CСXXXII : Праці Музикознавчої комісії. С. 539-540.

11. Тележинський Михайло. Муха А. Композитори України та української діаспори : довідник. Київ : Музична Україна, 2004. C. 293-294.

12. Телєжинський М. Українські колядки й щедрівки. Церква і нарід. 1938. Рік. IV. Ч. 1-2. 1-15 січня. С. 26-29.

13. Телєжинський М. Українська народна пісня. Микола Дмитрович Леонтович - український композитор (1877-1921). Українська нива. 1928. Ч. 8 (89). С. $3-4$.

14. Телєжинський М. Українська народна пісня. Українська нива. 1927. Ч. 51 (56). 28 вересня. С. 2.

15. Телєжинський М. Українська пісня. Кирило Григорович Стеценко - український композитор (1882-1922). Украӥнська нива. 1927. Ч. 57 (62). 24 жовтня. С. $3-4$; Ч. 58 (63). 28 жовтня. С. 4 ; Ч. 59 (64). 1 листопада. С. 4.

16. Телєжинський М. Український пісняр Микола Дмитрович Леонтович. Боян. 1930. Січень. № 1. С. 2-3.

17. Телєжинський М. Церковна музика. Церква і нарід. 1935. Рік. I. Ч. 14. 1 жовтня. С. 420-422 ; Ч. 15.15 жовтня. С. 450-454; Ч. 17. 15 листопада. С. 526-530.

18. Шиманський П. Музична культура Волині першої половини XX ст. Луцьк : Вежа, 2005. 172 с.

19. Шиманський П. Про що розповіли архіви <..>. Музика. 1997. № 1. С. 22-23, 28.

20. Шиманський П. Публіцистика М. Тележинського. Проблеми взаємодї мистецтв, педагогіки і практики освіти : збірник наукових праць. Харків, 1999. Вип. 4. С. 162-172.

21. Шиманський П. Хорова творчість волинських композиторів першої половини XX ст. : навчальний посібник. Луцьк : Волин. нац. ун-т ім. Лесі Українки, 2010. 258 с.

22. Філоненко Л., Молчко У. Жанр біографічного нарису в музичнопубліцистичній творчості Михайла Тележинського. Музичне життя 
Волині $X I X-X X \mathrm{~cm}$. : колективна монографія / В. Тиможинський та ін. ; заг. ред. П. Шиманського. Луцьк, 2012. С. 51-78.

23. Філоненко Л., Молчко У. Музикознавчо-публіцистичний нарис Михайла Тележинського 2Український композитор Микола Дмитрович Леонтович (1877-1921)» на сторінках часопису «Українська нива». Минуле і сучасне Волині та Полісся. Володимир-Волинський в історії Украӥни і Волині : науковий збірник. Луцьк, 2009. Вип. 32. С. 94-98.

24. Філоненко Л., Молчко У. Музикознавчі нариси Михайла Тележинського «Український пісняр Микола Дмитрович Леонтович (1877-1921)» і «Кирило Стеценко (1882-1922)». Музикознавчі студіï інституту мистецтв Волинського національного університету імені Лесі Украӥнки та Національної музичної академії Украӥни імені П.І. Чайковського : збірник наукових праць / упор. О. Коменда. Луцьк : Волин. нац. ун-т. ім. Лесі Українки, 2009. Вип. 4. С. 56-71.

25. Філоненко Л., Молчко У., Шиманський П. Із джерелознавчої спадщини : маловідома стаття Михайла Тележинського «Микола Лисенко». Музична украӥніка: сучасний вимір : збірник наукових статей. Вип. 7 : Постать Миколи Лисенка в європейському й національному історико-культурному контексті / ред.-упоряд. О. Кушнірук. Київ : ІМФЕ ім. М.Т. Рильського, 2012. С. 336-344.

\section{Information about the author:} Molchko U. B., Associated Professor at the Department of Science Musical Sciagraphy and Pianoforte

Education and Researcher Musical Art Institute of Drohobych Ivan Franko State Pedagogical University 24, Ivan Franko str., Drohobych, Lviv region, 82100, Ukraine 